\title{
Anti-37kDa antibodies are associated with the development of IDDM in individuals with islet cell antibodies
}

\author{
J.-C. Ongagna, C. Levy-Marchal \\ INSERM CJF 93-13, Hôpital Robert Debré, Paris, France
}

\begin{abstract}
Summary Antibodies directed against a beta-cell specific antigen with a molecular weight of $37 \mathrm{kDa}$ have recently been described. These anti-37kDa antibodies were measured by the immunoprecipitation technique in individuals at risk for insulin-dependent diabetes mellitus (IDDM), with islet cell antibodies (ICA) greater than 20 Juvenile Diabetes Foundation units (JDFU). These subjects were recruited from large population-based cohorts at various degrees of risk for developing the disease before adulthood. Anti-37kDa antibodies were measured in 25 ICA-positive first degree relatives with ICA greater than 20 JDFU, identified from a baseline cohort of 1,185 relatives (age: $0-75$ years). Four relatives were positive for anti-37kDa antibodies since the first determination onwards. These relatives developed IDDM in a 2-year follow-up period. We included 300 children with an IDDM parent, and aged less than 7 years, in a prospective survey for the prediction of IDDM. Five $(1.6 \%)$ showed ICA greater than 20 JDFU. None of them were found to be positive for anti$37 \mathrm{kDa}$ antibodies, and none have progressed to dia-
\end{abstract}

betes during a 2-year follow-up. Among a baseline cohort of 13,380 schoolchildren (age: $6-17$ years), 28 $(0.2 \%)$ were found to have ICA greater than 20 JDFU. One boy was positive for anti-37kDa antibodies on two consecutive occasions and developed IDDM after a 10 -month follow-up. No other schoolchildren with ICA greater than 20 JDFU were found to be positive for anti-37kDa antibodies. Altogether 40 other ICA-positive sera (with titres $<20$ JDFU) were found to be negative for anti-37kDa antibodies. With our assay, anti-37kDa antibodies were found to have a $76 \%$ sensitivity (95\%CI: $68-92 \%$ ) at the time of diagnosis in diabetic children. The current observations are based on a short-term follow-up. An analysis based on a longer period will be extremely useful for the prediction of IDDM and the appearance of anti-37kDa antibodies. [Diabetologia (1995) 38: 370-375]

Key words Insulin-dependent diabetes, islet cells antibodies, anti-37kDa antibodies, prediction, specificity.
Insulin-dependent diabetes (IDDM) in childhood is acknowledged as an auto-immune disease. A preclinical phase has been described in first-degree relatives, which is defined by detectable auto-antibody le-

Received: 6 March 1994 and in revised form: 29 September 1994

Corresponding author: Dr. C. Levy-Marchal, Service de Diabétologic, Hôpital Robert Debré, F-75019, Paris, France

Abbreviations: IDDM, insulin-dependent diabetes mellitus; ICA, islet cell antibodies; IAA, insulin auto-antibodies; JDFU, Juvenile Diabetes Foundation unit. vels for months or years before the clinical onset of the disease. Several auto-antibodies, such as islet cell antibodies (ICA) [1], insulin auto-antibodies [2], and anti-64kDa [3] appear to be involved in this long process. ICA represent the major risk marker used for identification of individuals at increased risk for subsequent development of IDDM [4-7]. High ICA titres ( $\geq 20$ JDFU) are associated with a positive predictive value of $73 \%$ over 8 years in first-degree relatives [9]. These observations have been made in firstdegree relatives where the cumulative risk for the disease is greatly enhanced, but who will provide only about $5 \%$ of the future cases. This is in comparison 
Table 1. Study populations

\begin{tabular}{lccc}
\hline & Parents and siblings & $\begin{array}{l}\text { Children from a } \\
\text { diabetic parent }\end{array}$ & $\begin{array}{c}\text { Children from the back- } \\
\text { ground population }\end{array}$ \\
\hline Initial cohort & 1185 & 300 & 13380 \\
ICA-positive $n(\%)$ & $65(5.5)$ & $13(4.3)$ & $198(1.5)$ \\
ICA $>$ 20 JDFU $n(\%)$ & $24(2.0)$ & $5(1.6)$ & $28(0.2)$ \\
Maximal follow-up (years) & 2 & 1.5 & 4 \\
\hline
\end{tabular}

with the background population where the risk is low, but where the large majority of the cases will develop. Data are very seldom available on the predictive value of ICA (or other auto-antibodies) in children from the background population.

A novel antigen has been described as an islet protein with a molecular weight of $37 \mathrm{kDa}[10]$. This protein is a tryptic fragment of the $64 \mathrm{kDa}$ component. Trypsin treatment can release a fragment of $50 \mathrm{kDa}$ and one of $37 \mathrm{kDa}$, which is a beta-cell-specific component of the membrane [11]. Antibodies against this polypeptide can be identified using the immunoprecipitation technique [10]. They have been given an $80 \%$ sensitivity in sera from IDDM patients at the time of diagnosis [10]. A positive predictive value of $100 \%$ has been reported in subjects at risk for IDDM such as identical twins [12], polyendocrine patients [13]. This remarkable value has only been attributed in subjects already known to be positive for ICA. These observations have been made so far in one country by a single scientific group that identified antibodies against the $37 \mathrm{kDa}$ molecule as the most specific known risk marker.

The aim of the present study was to test for the presence of anti-37kDa antibodies in individuals with ICA greater than 20 JDFU. These subjects, who are hypothetically at increased risk for IDDM, were identified among population-based cohorts of subjects at different risks for developing IDDM, such as parents and siblings, children with a diabetic parent, and children from the background population.

\section{Subjects and methods}

\section{Reference populations}

Children with IDDM. Children refered to the Department of Diabetology at the Robert Debré Hospital (Paris) were used as a reference population. The group was composed entirely of children recruited consecutively over 2 calendar years (1989-1990). There were 65 boys and 51 girls. The mean age at diagnosis was 9.6 years (range: $1-14$ years). A blood sample was drawn from each child within 10 days following initiation of insulin therapy.

Control children. The last 69 ICA-negative children from the background population cohort were used as control subjects. The age range was $7-16$ years.

\section{Populations at risk for progression to IDDM (Table 1)}

Parents and siblings of diabetic patients. In France the cumulative risk for the disease in these subjects up to the age of 22 years has been reported to be $6 \%$ [7].

A large screening programme was initiated in March 1992. The aim was to identify first degree relatives (parents and siblings) of diabetic children eligible for a future therapeutic prevention trial. Thirty-eight Paediatric Departments in France were asked to invite the diabetic families to participate in the screening programme. A total of 1,185 relatives were tested between March 1992 and March 1994, comprising 262 brothers, 291 sisters, 287 fathers and 345 mothers. Ages ranged from $0-75$ years at inclusion.

Irrespective of the ICA titre, positive for ICA detection was verified on a second sample, and the individuals were subsequently followed-up on a yearly basis. The ICA-negative relatives were not followed-up for ICA determination.

Offspring of diabetic parents. The cumulative risk for developing diabetes has been reported to be $5 \%$ in children with an IDDM parent [14]. The risk markers, however, are poorly documented in this population. In 1992 a prospective study was initiated in France to identify immune risk markers in young children with at least one diabetic parent and aged less than 7 years at the time of inclusion. Seventeen diabetic clinics around the country were involved in this recruitment network for IDDM parents who volunteered to have their children followed-up on a yearly basis for 5 years irrespective of the presence of ICA. IDDM in the parent was defined as diabetes permanently treated with insulin, with treatment having been initiated before the age of 36 years. The diagnosis was documented by the review of the detailed medical history and ascertained by two independent diabetologists. In December 1993, we recruited 300 children for the project and are included in the present survey. They were born in 287 families, from 115 diabetic mothers and 172 diabetic fathers. There were 158 sons and 142 daughters with a mean age at inclusion of $3.5 \pm 2.8$ years.

Schoolchildren. Sera from 13,380 children $(6,747$ boys and 6,633 girls) aged $6-17$ years, were anonymously screened for the presence of ICA. Sera were collected between October 1989 and June 1991 at the Institut Régional de Santé (IRSA, Tours) which is responsible for organizing and performing free health examinations on adults and their children with parental consent.

Blood was drawn to determine the fasting glucose level among other usual parameters with $1 \mathrm{mlimmediately} \mathrm{being} \mathrm{cen-}$ trifuged and the serum kept at $-80^{\circ} \mathrm{C}$ until ICA determination.

Results of ICA-positivity and information on the research programme were given to the family practitioners who were responsible for the follow-up of these children. Each year they were sent a questionaire asking about the diagnosis of diabetes or other autoimmune diseases. 
After the first determination all the ICA-positive children were subsequently asked for one blood sample. Blood was drawn in dry tubes $(5 \mathrm{ml})$ and sent directly to the central laboratory where ICA were determined on each occasion.

There is no follow-up information on the ICA-negative children. The protocol and design of the present research were approved by the Ethics Committee of the Medical School at Saint-Louis Lariboisière University, Paris, France.

\section{Analytical methods}

Immunoprecipitation of the anti-37kDa antibodies. The method originally described by Christie et al. [10] has been used. In summary, insulinoma cell proteins (Subclone RINm5F, INSERM U55, Paris, France) were radiolabelled with ${ }^{35} \mathrm{~S}$-methionine (Amersham, Les Ulis, France) for $5 \mathrm{~h}$ at $37^{\circ} \mathrm{C}$. Radiolabelled insulinoma cells $\left(25 \cdot 10^{6}\right.$ cells) were then homogenized on ice and centrifuged at $10,000 \mathrm{~g}$ for $30 \mathrm{~min}$ at $4^{\circ} \mathrm{C}$.

After two additional washes, trypsin treatment was performed on the particulate fraction. Prior to immunoprecipitation, trypsin extract was precleared overnight with normal human serum. Aliquots of extract at $4,000,000 \mathrm{cpm}$ of protein were incubated with $9 \mu \mathrm{l}$ of serum tested or standard serum 37$\mathrm{kDa}$ positive for $5 \mathrm{~h}$ at $4{ }^{\circ} \mathrm{C}$ and immune complexes were isolated on $25 \mu$ l of protein A-sepharose CL-4B. Immunoprecipitates were washed three times before denaturation. Immunoprecipitated proteins were separated according to molecular weight by SDS-PAGE technique. The $10 \%$ SDS gel was stained with Coomassie Brillant Blue G-250. After destaining, the gel was dried and autoradiographed for 2 weeks using X-OMAT diagnostic film (X AR-5, Kodak, Rochester, NY, USA).

Analytical controls. In each assay a negative and a positive serum were run. Furthermore, three dilutions $(1 / 4 ; 1 / 16 ; 1 / 32)$ of the positive sera were made up with the negative sera and stored in aliquots at $-80^{\circ} \mathrm{C}$. These dilutions were used in each run. The 1/32 dilution was at the limit of detection of our assay, and served as control of sensitivity in each run. No attempt was made to determine anti-37kDa antibodies titres in positive sera.

Islet cell antibodies. All ICA determinations were performed in one laboratory by the same technician. ICA were detected by the indirect immunofluorescence method using group $\mathrm{O}$ pancreata [15]. Titres were taken as the last serum dilution containing ICA positivity; each titre was then converted into JDF units as recommended by the 3rd International Workshop on Standardization of ICA [16]. Screening of all the sera from schoolchildren were performed on a single pancreas, on which the end-point dilution of the JDF standard serum was 1:64. The detection limit for an undiluted positive serum was $4 \mathrm{JDF}$ units (JDFU). Another pancreas was subsequently used for follow-up and the family study. The detection limit was 3 JDFU. During the screening procedure each positive serum was read by two independent observers; in case of discrepancy the sample was re-analysed in a further series. Any serum read at the limit of detection of the assay was always re-analysed in a second run. The assay was validated through our laboratory's participation in several Workshops on Standardisation on Immunology of Diabetes.

HLA DQB typing. HLA typing was performed by the identification of susceptibility alleles at the DQ region. The polymorphism of DQB1 locus was studied by differential restriction mapping as already described [17].
Table 2. Anti-37kDa antibodies in diabetic children

\begin{tabular}{cclc}
\hline $\begin{array}{l}\text { Age groups } \\
\text { (years) }\end{array}$ & $n$ & $\begin{array}{l}\text { anti-37kDa- } \\
\text { positive } n(\%)\end{array}$ & $\begin{array}{l}\text { anti-37kDa- } \\
\text { negative } n(\%)\end{array}$ \\
\hline $0-4$ & 17 & $16(94)$ & $1(6)$ \\
$5-9$ & 33 & $28(85)$ & $5(15)$ \\
$10-14$ & 66 & $44(67)$ & $22(33)$ \\
$0-15$ & 116 & $88(76)$ & $28(24)$ \\
\hline
\end{tabular}

Differences in frequencies among age groups: $p=0.03$

Table 3. Islet cells and anti-37kDa antibodies in diabetic children

\begin{tabular}{lc}
\hline ICA/37kDa & $n(\%)$ \\
\hline Positive/Positive & $79(68)$ \\
Positive/Negative & $19(16)$ \\
Negative/Positive & $9(8)$ \\
Negative/Negative & $9(8)$ \\
\hline
\end{tabular}

\section{Statistical analyses}

Data are expressed as means \pm SD or means and range. The chi-square test was used to compare frequency distributions in the different populations.

\section{Results}

\section{Anti-37kDa antibodies in the reference populations}

Anti-37kDa antibodies were detected in 88 of 116 ( $76 \%$ ) diabetic children at the time of clinical onset. There was a significant and inverse association between age and anti-37kDa positivity $\left(\chi^{2}=7.2 ; d f=2\right.$; $p=0.03)$; anti-37kDa antibodies were detected in $94 \%$ of the children in the younger age group (Table 2).

ICA were detected in $85 \%$ of the same diabetic children. Overlap in the determination of the two antibodies is indicated in Table 3 . Only $8 \%$ of the diabetic children were found to be positive for anti$37 \mathrm{kDa}$ antibodies and negative for ICA. Another $8 \%$ of the children were negative for the two antibodies at the time of clinical diagnosis.

No significant association was found between the presence of anti-37kDa antibodies and HLA-DQB1 genotypes (data not shown). Anti-37kDa antibodies were not found in any of the ICA-negative schoolchildren tested.

\section{Anti-37kDa antibodies in ICA-positive individuals from populations at various risks for IDDM (Table 4)}

Siblings and parents. From the initial cohort of 1,185 first-degree relatives, $65(5.5 \%)$ were found to be positive for ICA, among whom 24 (2.0\%) showed greater than 20 JDFU. These 24 sera were tested for anti- 
Table 4. Anti-37kDa antibodies in individuals with high ICA titres from populations at various risks for IDDM

\begin{tabular}{lcccc}
\hline Groups & $n$-tested sera & $\begin{array}{l}\text { Age mean years } \\
\text { (range) }\end{array}$ & $\begin{array}{l}37 \mathrm{kDa}+ \\
n\end{array}$ & $\begin{array}{l}\text { IDDM } \\
n\end{array}$ \\
\hline Siblings and parents & & $21.5(6-46)$ & 4 & 4 \\
Children from a diabetic parent & 25 & $3.4(1-6)$ & 0 & 0 \\
Children from the background population & 28 & $10.3(6-16)$ & 1 & 1 \\
\hline
\end{tabular}

$37 \mathrm{kDa}$ antibodies, which were detected in four sera at the first determination, and remained positive thereafter. After a maximal follow-up of 2 years, four siblings have progressed to clinical diabetes after an interval of 3-19 months. These four siblings had ICA greater than $20 \mathrm{JDFU}$ at the first determination and this level remained unchanged on subsequent occasions. The four individuals who were positive for anti-37kDa antibodies were the four siblings who subsequently developed diabetes.

Twenty-one sera, ICA-positive with titres less than $20 \mathrm{JDFU}$, were found to be negative for anti-37kDa antibodies.

Children with one diabetic parent. Among the 300 children younger than 7 years included in this survey, $13(4.3 \%)$ were found positive for ICA, of which 5 $(1.6 \%)$ had ICA titres greater 20 JDFU. These latter ICA-positive sera were tested for the presence of anti-37kDa antibodies, and none were found to be positive. None of these children have developed diabetes after a maximal follow-up of 18 months. Eight other sera, with ICA less than 20 JDFU, tested negative for anti-37kDa antibodies.

Given the strong association of anti-37kDa antibodies with the young age found in diabetic children, 13 ICA-negative sera were analysed from children age- and sex-matched to the ICA-positive children. They were found to be negative for the detection of anti-37kDa antibodies.

Children from the background population. From the initial cohort of 13,380 schoolchildren, 198 were found positive for ICA, and 28 had titres greater than $20 \mathrm{JDFU}$ at the first determination. The maximal follow-up was 4 years in the ICA-positive children. One boy has developed IDDM after a 10month interval; ICA were positive with 42 JDFU on two consecutive occasions and the genotype at the HLA-DQB1 locus was *0201/*0302.

The 28 sera with high ICA titres were analysed for anti-37kDa antibodies. Only one was found to be positive on two separate occasions, which was found to be the serum from the boy who subsequently became diabetic.

\section{Discussion}

Anti-37kDa antibodies were found in a very limited number of individuals at risk for IDDM. These subjects were isolated from groups at various risk for the disease, but all were found to have high ICA titres ( $\geq 20$ JDFU). The five children positive for anti$37 \mathrm{kDa}$ antibodies subsequently developed IDDM.

The same immune marker was given a sensitivity of $76 \%(95 \% \mathrm{CI}: 68-92 \%)$ in diabetic children at clinical onset. This sensitivity was of the same order of magnitude as that for ICA. The proportion of anti-37kDa antibodies-positive sera decreased with age. This is the first time that this association has been described for this antibody, but such an association has already been reported for other auto-antibodies involved in the diabetogenic process, such as insulin auto-antibodies (IAA) [18].

The high predictive value of anti-37kDa antibodies and high-titre-ICA combined is particularly interesting in view of intervention programmes for the prevention of the clinical phase in subjects at risk for IDDM. So far the only marker used in the design of clinical trials in first-degree relatives is high titre ICA. However ICA, even greater than 20 JDFU, are associated with a positive predictive value of $73 \%$ over an 8-year period in this population [9]. The addition of IAA seems to confer a higher predictive value on a short-term basis, but in this respect results are conflicting $[19,20]$. The use of anti-GAD antibodies has not yet been tested on a large scale and in a prospective analysis. From the preliminary data published they do not appear to confer a higher predictive value than ICA [21-23]. Anti-37kDa antibodies are therefore the first immune markers able to identify the subjects who will progress to the clinical disease among individuals with ICA greater than 20 JDFU. This observation has been made on a shortterm period only.

More interestingly, this observation was confirmed in the present study not only in relatives of diabetic children, but also in schoolchildren. In surveys from several countries it has been reported that ICA alone would not be sufficient for the prediction of IDDM in children from the background population [24-27]. In France for instance, the cumulative risk of developing overt diabetes up to the age of 22 years has been reported as being $6 \%$ in first degree relatives [7]. The same risk in children from the 
background population can be estimated at $0.1 \%$ from incidence data [28]. Very few epidemiological studies are dealing with the prediction of IDDM in children from the background population. Follow-up periods are too short in these population-based studies to calculate the predictive value of ICA on a long-term basis. A longer follow-up period will be necessary for the development of intervention trials. It is already known, however, that the specificity of ICA in the background population is insufficient. It has been observed in the state of Washington, USA [25] and in different countries, such as France [24], England [26], and Germany [27] that ICA were detectable in a far greater number of children than expected from incidence calculations for developing diabetes in subsequent years.

Data reported here confirmed the observations made in England in first-degree relatives where a $100 \%$ positive predictive value was found for anti$37 \mathrm{kDa}$ antibodies in association with ICA [29]. In this country, a similar and very high predictive value was also found in schoolchildren for anti-37kDa antibodies towards the prediction of subsequent IDDM, on a short-term basis [30]. To our knowledge this is the only country so far where data have been published on anti-37kDa antibodies. It would be a premature conclusion to extend these observations to any group at risk for IDDM prior to confirmation.

There are some fundamental restrictions to the observed data. Firstly, a substantial number of children have been found to be negative for the two antibodies at the time of clinical onset of IDDM. This may be due to a lack of analytical sensitivity of both procedures. The ICA assay described here, however, was able to detect antibodies at 3 JDFU. The children with no antibodies may represent a peculiar entity. On the other hand, data in the literature have failed to consistently document tight associations between immunogenetics and clinical presentation of diabetic children at the time of diagnosis [31-33]. In the present survey the negativity for the two antibodies was not associated with a specific HLA-DQB pattern.

All groups included in the present study have been followed for a short-term period. An analysis based on a longer period will be extremely useful for the prediction of IDDM. It would document the natural history of the appearance of anti-37kDa antibodies. Indeed, the groups studied for anti- $37 \mathrm{kDa}$ antibodies were restricted to ICA-positive individuals (greater than $20 \mathrm{JDFU}$ ), known to be at increased risk for the disease. This choice was made given the powerful value of ICA as a risk marker, already used as the "reference" marker. It was also based on practical considerations. The immunoprecipitation technique used for anti-37kDa antibodies is so far not applicable for large-scale screening. In the absence of information on ICA-negative children from any risk population it is not possible to draw a conclusion as to the remarkable specificity of anti-37kDa antibodies.

Acknowledgements. The authors are grateful to Drs. J.Tichet and F.Dubois from IRSA for their collaboration in the programme on the prediction of IDDM in schoolchildren. They are also indebted to all the physicians involved in this survey for their valuable contribution in the follow-up of the children and their families. This study has been performed with the skillful technical asistance of M.Hairy. This work was partly supported by a grant from the Aide aux Jeunes Diabétiques, Paris, France.

\section{References}

1. Tarn AC, Thomas JM, Dean BM et al. (1988) Predicting insulin-dependent diabetes. Lancet i: $8545-8550$

2. Srikanta S, Ricker AT, Mac Culloch DK, Sœldner JS, Eisenbarth GS, Palmer JP (1986) Autoimmunity to insulin, beta cell dysfunction and development of insulin-dependent diabetes mellitus. Diabetes 35: 139-142

3. Baekkeskov S, Landin M, Kristenson JK et al. (1987) Antibodies to a $64000 \mathrm{M}$ human islet cell antigen precede the clinical onset of insulin-dependent diabetes. J Clin Invest 79: 926-934

4. Tarn AC, Thomas JM, Dean BM et al. (1988) Predicting insulin-dependent diabetes. Lancet i:8545-8550

5. Riley WJ, Mac Laren N, Krischer J et al. (1990) A prospective study of the development of diabetes in relatives of patients with insulin-dependent diabetes. New Engl J Med 323: $1167-1172$

6. Thivolet C, Beaufrère B, Gebuhrer L, Chatelain P, Orgiazzi J (1991) Autoantibodies and genetic factors associated with the development of type 1 (insulin-dependent) diabetes in first-degree relatives of diabetic patients. Diabetologia 34: 186-191

7. Deschamps I, Boitard C, Hors J et al. (1992) Life table analysis of the risk of type 1 (insulin-dependent) diabetes mellitus in siblings according to islet cell antibodies and HLA markers. An 8-year prospective study. Diabetologia 35: 951-957

8. Knip M, Vähäsalo P, Karjalainen J et al. (1994) Natural history of preclinical IDDM in high risk siblings. Diabetologia 37: 388-393

9. Bonifacio E, Bingley PJ, Shattock M et al. (1990) Quantification of islet-cell antibodies and prediction of insulin-dependent diabetes. Lancet 335: 147-149

10. Christie MR, Vohra G, Champagne P, Danemen D, Delovitch TL (1990) Distinct antibody specificities to a $64 \mathrm{kDa}$ islet cell antigen in type 1 diabetes as revealed by trypsin treatment. J Exp Med 172: 789-795

11. Christie M. (1993) Characterization of distinct islet protein autoantigens associated with type 1 diabetes. Autoimmunity 15 [Suppl 1]: 1-3

12. Christie M, Tun RYM, Lo SSS et al. (1992) Antibodies to GAD and tryptic fragments of islet $64 \mathrm{k}$ antigen as distinct markers for development of IDDM; studies with identical twins. Diabetes 41: 782-787

13. Wagner R, Genovese S, Bosi E et al. (1994) Slow metabolic deterioration towards diabetes in islet cell antibody positive patients with autoimmune polyendocrine disease. Diabetologia 37: 365-371

14. Warram JH, Martin BC, Krolewski AS (1990) Possible mechanisms for the diminished risk of IDDM in the children of diabetic mothers. In: Andreani (ed) Immunobiolo- 
gy of normal and diabetic pregnancy. John Wiley and sons, Chichester, pp 221

15. Bottazzo GF, Gleichman H (1986) Immunology and diabetes workshops: report of the first international workshop on the standardisation of cytoplasmic islet cell antibodies. Diabetologia 29: 125-126

16. Boitard C, Bonifacio E, Bottazzo GF, Gleichmann H, Molenaar J (1988) Report on the third international workshop on the standardisation of cytoplasmic islet cell antibodies. Diabetologia 31: 451-452

17. Vallet-Colom I, Lévy-Marchal C, Zarrouk D et al. (1990) HLA-DQB1 codon 57 and genetic susceptibility to type 1 (insulin-dependent) diabetes mellitus French children. Diabetologia 33: 174-175

18. Lévy-Marchal C, Bridel MP, Sodoyez-Goffaux F et al. (1991) Superiority of radiobinding assay over ELISA for detection of insulin auto-antibodies in newly diagnosed type 1 diabetic children. Diabetes Care 14: 61-63

19. Dean BM, Becker F, Mc Nally JM et al. (1986) Insulin autoantibodies in the pre-diabetic period: correlation with islet cell antibodies and development of diabetes. Diabetologia 29: 339-342

20. Srikanta S, Ricker AT, McCulloch DK, Sceldner JS, Eisenbarth GS, Palmer JP (1986) Autoimmunity to insulin, beta cell dysfunction, and development of insulin-dependent diabetes mellitus. Diabetes 29: 339-342

21. Thivolet CM, Tappaz M, Durand A et al. (1992) Glutamic acid decarboxylase (GAD) autoantibodies are additional predictive markers of type 1 diabetes mellitus in high risk individuals. Diabetologia 35: 570-576

22. Christie MR, Tun RYM, Lo SSS et al. (1992) Antibodies to GAD and tryptic fragments of islet $64 \mathrm{kD}$ antigen as distinct markers for development of IDDM. Diabetes 41 : 782-787

23. Anstoot HJ, Sigurdsson E, Jaffe M et al. (1994) Value of antibodies to GAD 65 combined with islet cell cytoplasmic antibodies for predicting IDDM in a childhood population. Diabetologia 37: 917-924
24. Lévy-Marchal C, Tichet J, Fajardy I, Gu XF, Dubois F, Czernichow P (1992) Islet cell antibodies in normal French schoolchildren. Diabetologia 35: 577-582

25. Rowe R, Leech N, Nepom G, McCulloch D(1994) High genetic risk for IDDM in the Pacific Northwest. First report from Washington State. Diabetes prediction study. Diabetes 43: 87-94

26. Bingley P, Bonifacio E, Shattock M et al. (1993) Can islet cell antibodies predict IDDM in the general population? Diabetes Care 16: 45-50

27. Boehm BO, Manfras B, Seissler J, Schöffling K, Holzberger G, Seidl S et al. (1991) Epidemiology and immunogenetic background of islet cell antibody-positive nondiabetic schoolchildren. Diabetes 40: 1435-1439

28. Lévy-Marchal C, Papoz L, de Beaufort C et al. (1990) Incidence of juvenile type 1 diabetes in France. Diabetologia 33: $465-469$

29. Bingley PJ, Christie MR, Bonfanti R et al. (1993) Combined analysis of auto-antibodies in prediction of type 1 (insulin-dependent) diabetes.Diabetologia 36 [Suppl 1]: A36 (Abstract)

30. Genovese S, Bonifacio E, Bingley PJ et al. (1993) Anti-37 $\mathrm{kD}$ are specific markers for type 1 diabetes in ICA-positive school children. Diabetologia 36 [Supp1 1]: A98 (Abstract)

31. Lévy-Marchal C, Czernichow P, the French incidence study group.(1993) Heterogeneity of type 1 diabetes at onset in children: results from the French incidence study. Diab Métab 19: 296-303

32. Mustonen A, Ilonen J, Tiilikainen A, Kataja M, Åkerblom HK (1985) An analysis of epidemiological data in HLAtyped diabetic children. Diabetologia 28: $397-400$

33. Vandewalle CL, Decraene T, Schuit FC et al. (1993) Insulin auto antibodies and high titre islet cell antibodies are preferentially associated with the HLA DQA1*0301-DQB1*0302 haplotype at clinical onset of type 1 (insulin-dependent) diabetes mellitus before age 10 years, but not at onset between age 10-40 years. Diabetologia 36: $1155-1162$ 